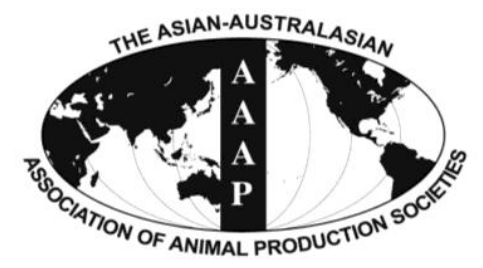

Asian Australas. J. Anim. Sci.

Vol. 26, No. 8 : 1137-1143 August 2013

http://dx.doi.org/10.5713/ajas.2013.13181

www.ajas.info

pISSN 1011-2367 elSSN 1976-5517

\title{
Effect of Saccharomyces cerevisiae Fermentation Product on Lactation Performance and Lipopolysaccharide Concentration of Dairy Cows
}

\author{
Rui-yang Zhang, Ilkyu Yoon ${ }^{1}$, Wei-yun Zhu, and Sheng-yong Mao* \\ College of Animal Science and Technology, Nanjing Agricultural University, Nanjing 210095, China
}

\begin{abstract}
To evaluate lactation performance and changes in plasma and fecal lipopolysaccharide (LPS) concentrations in response to the supplementation of Saccharomyces cerevisiae fermentation product (SC), two dairy farms were selected. On each farm, 32 cows in early to mid lactation (21 to 140 DIM) were blocked by parity and days in milk (DIM), and randomly assigned to one of the two treatments within block (Control or $56 \mathrm{~g} \mathrm{SC/cow/d).} \mathrm{Effect} \mathrm{of} \mathrm{SC} \mathrm{on} \mathrm{lactation} \mathrm{performance} \mathrm{(daily)} \mathrm{and} \mathrm{changes} \mathrm{in} \mathrm{blood} \mathrm{and} \mathrm{fecal} \mathrm{LPS}$ level were examined on $\mathrm{d} 0$ and 28 of supplementation. The results showed that SC supplementation increased lactation performance of dairy cows on both farms. On Farm 1, milk production, 3.5\% fat corrected milk (FCM), and yield of milk fat and protein were greater $(\mathrm{p}<0.01)$ for cows supplemented with SC. Supplementation of SC increased percentage milk fat $(\mathrm{p}=0.029)$ from 81 to 110 DIM. There was no significant effect ( $p>0.05$ ) of SC supplementation on percentage of milk protein, dry matter intake and feed efficiency. On Farm 2 , cows supplemented with SC had a greater $(\mathrm{p}<0.05)$ milk yield, percentage of milk fat and milk protein, yield of milk fat and protein, 3.5\% FCM and feed efficiency. Supplemental SC had no effect on LPS concentrations in feces ( $\mathrm{p}>0.05)$ while it trended to reduce ( $\mathrm{p}=$ 0.07 or 0.207 ) the concentration in plasma. The results indicate that supplemental SC can increase lactation performance of dairy cattle and has potential for reducing plasma LPS concentration. (Key Words: Dairy Cow, Saccharomyces cerevisiae Fermentation Product, Performance, LPS)
\end{abstract}

\section{INTRODUCTION}

As the supply of high quality forage is limited in China, dairy cows are often fed high concentrate diets with low quality forages, putting dairy cows in China at a higher risk of metabolic disease, such as sub-acute ruminal acidosis (SARA), displaced abomasum, ketosis, and fatty liver. Recent research has highlighted the role of high grain feeding in metabolic diseases and has suggested that endotoxin is involved in metabolic diseases (Gozho et al., 2005; Li et al., 2010). It has been shown that high-grain feeding increases rumen and fecal concentrations of free lipopolysaccharide (LPS), which is due to an increase in lysis of gram-negative bacteria (Gozho et al., 2005). Li et al. (2010) reported that high-grain feeding increased fermentation and the production of bacterial toxins in the hindgut of dairy cows. These recent scientific advancements suggest that there may be a correlation between high-grain feeding and fecal LPS and may allow the use of fecal LPS

\footnotetext{
* Corresponding Author: Sheng-yong Mao. Tel: +86-025-84395 523, Fax: +86-025-84395314, E-mail: maoshengyong@163.com

${ }^{1}$ Diamond V Mills, Cedar Rapids, IA, USA.

Submitted Apr. 2, 2013; Accepted Apr. 28, 2013; Revised May 8, 2013
}

as a diagnostic or management tool for the gut health. On the other hand, enhanced blood LPS concentration may be indicative of health problems such as mastitis or metritis (Pejsak and Tarasiuk, 1989). Therefore, application of blood and fecal LPS assays could be an additional management tool for dairies to monitor the health status of the animals. However, information on blood and fecal LPS concentrations in lactating dairy cows on commercial dairies in China is limited.

Saccharomyces cerevisiae fermentation product (SC), has been shown to improve lactation performance when the rumen was challenged with highly fermentable carbohydrates (Longuski et al., 2009). Stimulating rumen fermentation (Miller-Webster et al., 2002) and stabilizing rumen environment evidenced by a reduction in ruminal LPS concentration under SARA induction condition ( $\mathrm{Li}$ et al., 2012) indicates that the addition of SC may have a beneficial effect on the cow's health and performance. Thus, the objectives of the present study were: i) to evaluate the effect of SC on lactation performance; ii) to establish a baseline level of blood and fecal LPS of lactating dairy cows from commercial dairies; iii) to determine the effect of SC on blood and fecal LPS level. 


\section{MATERIALS AND METHODS}

All experiments were performed in accordance with the guidelines of the Animal Ethics Committee of Jiangsu province (China) and were approved by the Institutional Animal Care and Use Committee of Nanjing Agricultural University, China.

\section{Animals and diets}

Two commercial dairy farms were identified as nonDiamond V users near Nanjing, China. On each farm, 32 cows in early to mid lactation (21 to $140 \mathrm{~d}$ of lactation) were selected, blocked by parity (primiparous and multiparous), days in milk (DIM) and somatic cell count (SCC), and then randomly assigned to one of the two treatments, control or SC (Original SC Yeast Culture, Diamond V Mills, Cedar Rapids, Iowa, USA) within block. All cows received the same basal feed. Cows supplemented with SC received $56 \mathrm{~g} \mathrm{SC/cow/d,} \mathrm{top-dressed} \mathrm{in} \mathrm{the}$ morning feeding for $28 \mathrm{~d}$. Control cows received 56 $\mathrm{g} / \mathrm{cow} / \mathrm{d}$ of grain mixtures (1:1 mixture of corn and soybean meal), top-dressed in the morning feeding for $28 \mathrm{~d}$. The cows were housed in tie stalls with free access to water at all times. Diets were fed as a TMR with ratios of forage to concentrate of 48:52 and 45:55 for Farm 1 and Farm 2, respectively. Cows were fed for ad libitum intake twice daily at 0400 and $1400 \mathrm{~h}$ in equal portions. The amount of feed offered was adjusted daily to obtain approximately $10 \%$ orts (as-fed basis).

Diets were formulated to meet or exceed the nutrient requirements of a $600-\mathrm{kg}$ lactating cow according to NRC (2001) guidelines. Diet ingredients were analyzed for concentrations of dry matter (DM), crude protein (CP), neutral detergent fiber (NDF), acid detergent fiber (ADF), calcium $(\mathrm{Ca})$ and phosphorous $(\mathrm{P})$. The DM concentration was determined by drying samples at $105^{\circ} \mathrm{C}$ for $2 \mathrm{~h}$ (AOAC 1990). Methods of Van Soest et al. (1991) were used in analyses of NDF and ADF using heat-stable amylase and sodium sulfite in the case of NDF. The $\mathrm{CP}(\mathrm{N} \times 6.25)$ was determined by the method of Krishnamoorthy et al. (1982). The $\mathrm{Ca}$ and $\mathrm{P}$ content were analyzed according to Official Analytical Chemist (AOAC, 1990) method. Ingredients and nutrient composition of the TMR are presented in Table 1.

\section{Sample collection}

Cows were milked three times daily in their stall at approximately 0400, 1200, and $2000 \mathrm{~h}$. Milk yield was recorded daily. Milk samples were collected at every milking on d $0,8,15,22$ and 28 of experiment period and were analyzed for protein, fat and lactose by infrared analysis with a Fossmatic-605 (Foss Electric, Hillerod, Denmark). The amounts of TMR offered and refused were measured and recorded daily, and DMI was calculated on $\mathrm{d}$ $0,8,15,22$ and 28 of experiment period of each period.
Table 1. Ingredient and nutrient compositions of experimental diets

\begin{tabular}{|c|c|c|}
\hline 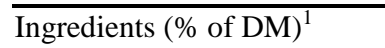 & Farm 1 & Farm 2 \\
\hline Alfalfa hay & 15.0 & 12.0 \\
\hline Leymus chinensis & 3.0 & 9.0 \\
\hline Wheat straw & 5.0 & 9.0 \\
\hline Maize silage & 25.0 & 15.0 \\
\hline Maize & 27.0 & 30.0 \\
\hline Wheat bran & 3.0 & 1.4 \\
\hline Soybean meal & 12.85 & 15.0 \\
\hline Cottonseed meal & 6.0 & 5.0 \\
\hline Calcium carbonate & 0.4 & 0.85 \\
\hline Calcium hydrogen phosphate & 0.75 & 0.75 \\
\hline Sodium bicarbonate & 0.75 & 0.75 \\
\hline Sodium chloride & 0.5 & 0.5 \\
\hline Dairy premix ${ }^{2}$ & 0.75 & 0.75 \\
\hline \multicolumn{3}{|c|}{ Nutrient composition (\% of DM) } \\
\hline $\mathrm{NE}_{\mathrm{L}}(\mathrm{Mcal} / \mathrm{kg}$ of DM) & 1.59 & 1.63 \\
\hline Crude protein & 15.4 & 15.9 \\
\hline Neutral detergent fiber & 38.9 & 28.7 \\
\hline Acid detergent fiber & 26.0 & 23.2 \\
\hline Non-fiber carbohydrates & 37.1 & 38.3 \\
\hline Calcium & 0.89 & 0.85 \\
\hline Phosphorous & 0.52 & 0.56 \\
\hline
\end{tabular}

On d 0 and 28, fecal grab samples (approximately $50 \mathrm{~g}$ ) were collected at $0300 \mathrm{~h}$ before morning feed delivery and blood was drawn from the tail vein using heparinized vacutainers (Becton Dickinson, NJ, USA) from each cow at $0330 \mathrm{~h}$ before morning feeding. Samples were placed in a cooler and delivered to the lab immediately. Blood and fecal LPS concentrations were determined in duplicates per sample.

\section{LPS analysis in fecal samples}

About $35 \mathrm{~g}$ fecal samples were transferred into a $50 \mathrm{ml}$ centrifuge tube and centrifuged at $13,000 \times \mathrm{g}$ for $40 \mathrm{~min}$ at $4^{\circ} \mathrm{C}$. Once centrifuged, all tubes were removed gently from the centrifuge and $5 \mathrm{ml}$ of the supernatant was aspirated into a syringe. Free LPS content in supernatant was determined by the Limulus Amebocyte Lysate (LAL) assay (Xiamen Houshiji, Ltd., Xiamen, China). Pretreated fecal samples were diluted until their LPS concentrations were in the range of 0.1 to 1 endotoxin units $(\mathrm{EU}) / \mathrm{ml}$ relative to the reference endotoxin (Escherichia coli O111:B4) and assayed as described by Gozho et al. (2005).

\section{LPS analysis in blood plasma samples}

As described by Khafipour et al. (2009), the concentration of LPS in the plasma was determined by the 
Table 2. Pre-trial (d 0) milk yield, dry matter intake and fecal and plasma LPS

\begin{tabular}{|c|c|c|c|c|}
\hline & Control & $\mathrm{SC}^{1}$ & SEM & p-value \\
\hline \multicolumn{5}{|l|}{ Farm 1} \\
\hline Milk yield (kg/d) & 19.6 & 19.8 & 0.329 & 0.730 \\
\hline Dry matter intake $(\mathrm{kg} / \mathrm{d})$ & 19.2 & 18.9 & 0.197 & 0.352 \\
\hline Fecal LPS $(\mathrm{EU} / \mathrm{ml})^{2}$ & 7,326 & 7,290 & 709 & 0.976 \\
\hline Plasma LPS $(\mathrm{EU} / \mathrm{ml})^{2}$ & 0.46 & 0.46 & 0.152 & 0.990 \\
\hline \multicolumn{5}{|l|}{ Farm 2} \\
\hline Milk yield (kg/d) & 21.5 & 21.7 & 0.542 & 0.835 \\
\hline Dry matter intake $(\mathrm{kg} / \mathrm{d})$ & 18.9 & 18.9 & 0.175 & 0.874 \\
\hline Fecal LPS $(\mathrm{EU} / \mathrm{ml})^{2}$ & 6,668 & 7,984 & 665 & 0.283 \\
\hline Plasma LPS $(\mathrm{EU} / \mathrm{ml})^{2}$ & 0.24 & 0.15 & 0.031 & 0.157 \\
\hline
\end{tabular}

${ }^{1} \mathrm{SC}=56 \mathrm{~g} / \mathrm{cow} / \mathrm{d}$, Diamond V Original XP, Diamond V, Cedar Rapids, Iowa, USA.

${ }^{2}$ LPS $=$ Lipopolysaccharide. EU = Endotoxin unit.

LAL assay (Xiamen Houshiji, Ltd., Xiamen, China) with a minimum detection limit of $0.01 \mathrm{EU} / \mathrm{ml}$. Before the LAL assay, samples were pretreated as described by Khafipour et al. (2009). Frozen plasma samples were thawed at $37^{\circ} \mathrm{C}$ and vortexed. Then, $100 \mu \mathrm{l}$ of each sample was diluted at least 10 -fold with pyrogen-free water. Diluted samples were incubated at $37^{\circ} \mathrm{C}$ for $30 \mathrm{~min}$, heated at $75^{\circ} \mathrm{C}$ for $15 \mathrm{~min}$ and cooled to room temperature $\left(19^{\circ} \mathrm{C}\right)$ for $45 \mathrm{~min}$. The LAL assay was performed using a 96 well microplate according to the manufacturer's instructions. All of the samples were tested in duplicate, and optical density values were measured using a microplate spectrophotometer (Spectramax 190, Molecular Devices Corporation, CA, USA) at a wavelength of $405 \mathrm{~nm}$. Results were accepted when the intra-assay coefficient of variation was $<10 \%$.

\section{Statistical analysis}

The $3.5 \%$ FCM and feed efficiency were calculated according to the following formulae: $3.5 \% \mathrm{FCM}=($ milk $\mathrm{kg}$ $\times 0.432)+($ fat $\mathrm{kg} \times 16.216)$; Milk efficiency $=$ milk yield/ DMI. To test the influence of SC supplementation on dry matter intake, milk protein $\%$, milk fat $\%$, milk yield, milk fat yield, milk protein yield, 3.5\% FCM and feed efficiency, the MIXED procedure of SPSS 18.0 (SPSS Inc, Chicago, IL, USA) was performed using diet, DIM and days of experiment as fixed effects and d 0 values as a covariate.
Samples collected on different day for the same cow were considered as repeated measures in the analysis of variance (ANOVA). For the LPS data, the general linear model (GLM) procedure of SPSS 18.0 (SPSS Inc, Chicago, IL, USA) was performed with diet and DIM as fixed effects and d 0 values as a covariate. Significance was declared at $\mathrm{p} \leq 0.05$ and a tendency was considered to exist at $0.05<\mathrm{p}<0.10$.

\section{RESULTS}

\section{Pre-trial production performance and the baseline level of LPS in plasma and feces}

No significant differences $(p>0.05)$ in pre-trial $(d 0)$ milk yield, DMI, and LPS levels in plasma and feces between control and SC were noted on both farms (Table 2). Milk yield and DMI ranged between 19.6 and $21.7 \mathrm{~kg} / \mathrm{d}$, and 18.9 and $19.2 \mathrm{~kg} / \mathrm{d}$, respectively. Plasma LPS levels ranged from 0.15 to $0.46 \mathrm{EU} / \mathrm{ml}$. Fecal LPS ranged from 6,668 to $7,984 \mathrm{EU} / \mathrm{ml}$.

\section{Effect of SC on production performance}

On Farm 1, yield of milk ( $\mathrm{p}=0.009)$, milk fat $(\mathrm{p}=$ $0.003)$, milk protein $(\mathrm{p}=0.005)$ and $3.5 \%$ FCM $(\mathrm{p}=0.001)$ increased when cows received the SC-supplemented diet (Table 3). No significant changes $(\mathrm{p}>0.05)$ were observed

Table 3. Effect of yeast culture supplementation $(\mathrm{SC})^{1}$ on milk yield and milk composition on Farm 1

\begin{tabular}{|c|c|c|c|c|c|c|}
\hline \multirow{2}{*}{ Item } & \multirow{2}{*}{ Control } & \multirow{2}{*}{$\mathrm{SC}$} & \multirow{2}{*}{ SEM } & \multicolumn{3}{|c|}{ p-value } \\
\hline & & & & $\mathrm{SC}$ & DIM & $\mathrm{SC} \times \mathrm{DIM}$ \\
\hline Dry matter intake $(\mathrm{kg} / \mathrm{d})$ & 18.7 & 19.0 & 0.211 & 0.505 & 0.436 & 0.417 \\
\hline Milk yield (kg/d) & 19.5 & 20.4 & 0.226 & 0.009 & $<0.001$ & 0.084 \\
\hline Milk fat $(\%)$ & 3.12 & 3.24 & 0.052 & 0.219 & 0.170 & 0.003 \\
\hline Milk protein (\%) & 2.97 & 3.00 & 0.017 & 0.376 & 0.001 & 0.377 \\
\hline Milk fat yield (kg/d) & 0.60 & 0.66 & 0.008 & 0.003 & 0.008 & 0.79 \\
\hline Milk protein yield $(\mathrm{kg} / \mathrm{d})$ & 0.58 & 0.61 & 0.009 & 0.005 & $<0.001$ & 0.169 \\
\hline $3.5 \%$ FCM $(\mathrm{kg} / \mathrm{d})$ & 18.1 & 19.5 & 0.211 & 0.001 & $<0.001$ & 0.408 \\
\hline Feed efficiency & 0.99 & 1.04 & 0.016 & 0.165 & 0.054 & 0.265 \\
\hline
\end{tabular}

${ }^{1} \mathrm{SC}=56 \mathrm{~g} / \mathrm{cow} / \mathrm{d}$, Diamond V Original XP, Diamond V, Cedar Rapids, Iowa, USA. 


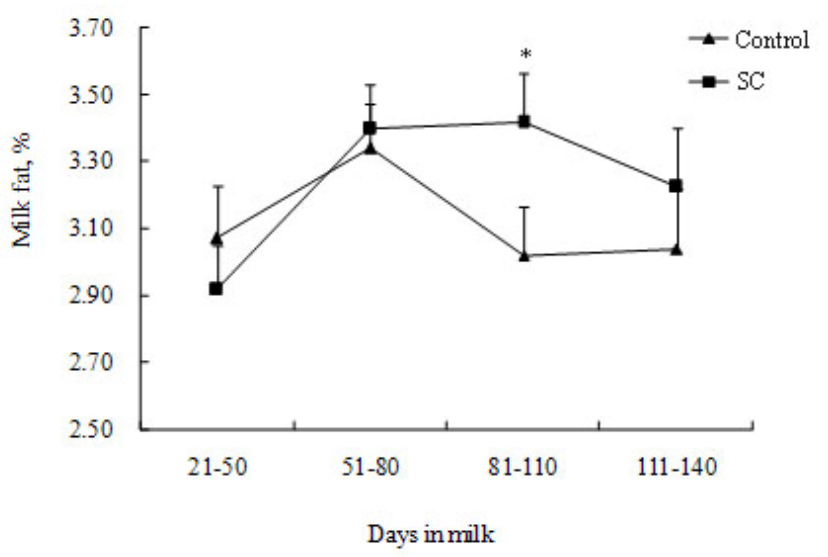

Figure 1. Interaction between SC and DIM on percentage of milk fat (Farm 1). SC was fed at $56 \mathrm{~g} / \mathrm{cow} / \mathrm{d}$ (Diamond V Original XP, Diamond V, Cedar Rapids, Iowa, USA). Note: symbol on the top of standard error bars indicate the significance of the differences between data for control and SC treatment.

on percentage of milk fat and protein and dry matter intake. A significant SC by DIM interaction $(p=0.003)$ was observed for percentage of milk fat. Effect of SC in milk fat \% increased as DIM progresses (Figure 1).

On Farm 2, the average daily milk yield $(\mathrm{p}=0.017)$, milk protein $\%(\mathrm{p}<0.001)$, milk fat $\%(\mathrm{p}=0.009)$, milk fat yield $(\mathrm{p}=0.002)$, milk protein yield $(\mathrm{p}=0.001), 3.5 \%$ FCM $(\mathrm{p}=0.002)$ and feed efficiency $(\mathrm{p}=0.011)$ were significantly increased with SC supplementation (Table 4). Significant SC by DIM interactions were observed in milk yield $(p=0.028)$, percentage of milk protein $(p<0.001)$ and milk fat $(\mathrm{p}=0.049)$, and milk protein yield $(\mathrm{p}=0.030)$ (Figure $2 \mathrm{a}, 2 \mathrm{~b}, 2 \mathrm{c}$ ). Supplementation of SC resulted in an increased milk production ( $\mathrm{p}<0.001)$ from 111 to 140 DIM. Milk fat $(p<0.05)$ concentrations were greater for cows fed SC from 51 to 110 DIM. Cows from 51 to 140 DIM supplemented with SC had higher percentage of milk protein $(\mathrm{p}<0.05)$

Effect of SC on free LPS concentration in blood and feces

The effects of SC supplementation on free LPS levels in blood and feces are shown in Table 5. Supplementation of $\mathrm{SC}$ tended to decrease $(\mathrm{p}=0.07)$ LPS in plasma in Farm 2, with only a numerical reduction $(\mathrm{p}=0.207)$ in Farm 1 . Plasma LPS concentration increased $(\mathrm{p}<0.05)$ as DIM progresses (Figure 3). Supplementation of SC did not affect (p>0.05) fecal LPS concentrations. Effect of DIM on fecal LPS concentration was not clearly ascertained. There was a significant increase in fecal LPS with increasing DIM on Farm $1 \quad(p<0.001)$, while no significant change was observed in Farm 2. In addition, there was no significant ( $>0.10)$ SC by DIM interaction for LPS levels in plasma and feces.

\section{DISCUSSION}

A recent meta-analysis conducted by Poppy et al. (2012) has shown that SC increases production performance of lactating dairy cows. The increase in milk production estimated for cows fed SC in peer reviewed studies was 1.2 $\mathrm{kg} / \mathrm{d}$ more milk, $1.6 \mathrm{~kg} / \mathrm{d}$ more $3.5 \%$ FCM or $1.7 \mathrm{~kg} / \mathrm{d}$ more energy corrected milk. Dry matter intake was estimated to increase by $0.6 \mathrm{~kg} / \mathrm{d}$ in cows less than 70 DIM and decreased by $0.8 \mathrm{~kg} / \mathrm{d}$ in cows later in lactation. In the present study, supplementation of SC significantly improved milk yield on both farms. The range of increase in milk production (1.0 kg/d in Farm 1 and $1.4 \mathrm{~kg} / \mathrm{d}$ in Farm 2) is consistent with the results of the meta-analysis $(1.2 \mathrm{~kg} / \mathrm{d}$, Poppy et al., 2012). These effects of SC may be due to the stabilizing effect on rumen fermentation, such as increasing lactate-utilizing bacteria (Callaway and Martin, 1997). The stabilized rumen condition allows increased growth and activity of fiber-digesting bacteria (Harrison et al., 1988), resulting in improved fiber digestion (Yoon and Garrett, 1998).

The meta-analysis also reported that $\mathrm{SC}$ increased milk fat yield $(0.06 \mathrm{~kg} / \mathrm{d} ; \mathrm{p}=0.009)$ and milk protein yield $(0.03$ $\mathrm{kg} / \mathrm{d} ; \mathrm{p}=0.026)$. However, the paper did not report changes in percentage of milk fat or protein. In the present study, percentage of milk fat was positively affected by SC supplementation (3.12 to $3.24 \%$ in Farm 1 and 2.79 to

Table 4. Effect of yeast culture supplementation (SC) ${ }^{1}$ on milk yield and milk composition on Farm 2

\begin{tabular}{|c|c|c|c|c|c|c|}
\hline \multirow{2}{*}{ Item } & \multirow{2}{*}{ Control } & \multirow{2}{*}{$\mathrm{SC}$} & \multirow{2}{*}{ SEM } & \multicolumn{3}{|c|}{ p-value } \\
\hline & & & & $\mathrm{SC}$ & DIM & $\mathrm{SC} \times \mathrm{DIM}$ \\
\hline Dry matter intake $(\mathrm{kg} / \mathrm{d})$ & 18.5 & 18.8 & 0.182 & 0.313 & 0.035 & 0.061 \\
\hline Milk yield (kg/d) & 18.0 & 19.4 & 0.412 & 0.017 & $<0.001$ & 0.028 \\
\hline Milk fat (\%) & 2.79 & 3.11 & 0.065 & 0.009 & 0.008 & 0.049 \\
\hline Milk protein $(\%)$ & 2.97 & 3.08 & 0.012 & $<0.001$ & $<0.001$ & $<0.001$ \\
\hline Milk fat yield (kg/d) & 0.50 & 0.61 & 0.019 & 0.002 & 0.001 & 0.371 \\
\hline Milk protein yield $(\mathrm{kg} / \mathrm{d})$ & 0.53 & 0.59 & 0.013 & 0.001 & $<0.001$ & 0.030 \\
\hline $3.5 \%$ FCM $(\mathrm{kg} / \mathrm{d})$ & 15.9 & 18.3 & 0.338 & 0.002 & 0.035 & 0.362 \\
\hline Feed efficiency & 0.87 & 0.99 & 0.020 & 0.011 & $<0.001$ & 0.218 \\
\hline
\end{tabular}

${ }^{1} \mathrm{SC}=56 \mathrm{~g} / \mathrm{cow} / \mathrm{d}$, Diamond V Original XP, Diamond V, Cedar Rapids, Iowa, USA. 

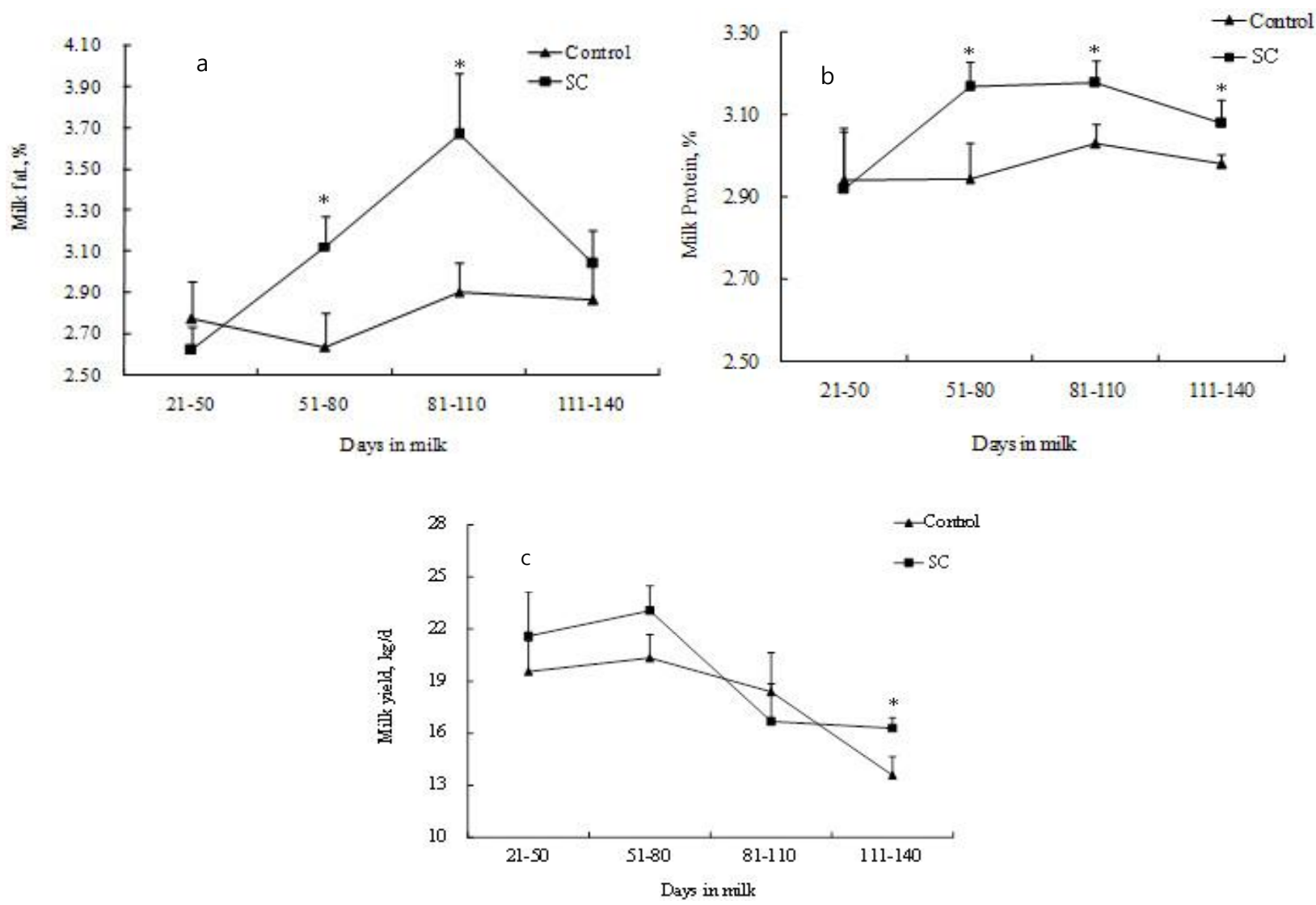

Figure 2. Interaction between SC and DIM on percentage of milk fat (a) and milk protein (b), and milk yield (c) (Farm 2). SC was fed at $56 \mathrm{~g} / \mathrm{cow} / \mathrm{d}$ (Diamond V Original XP, Diamond V, Cedar Rapids, Iowa, USA). Note: symbols on the top of standard error bars indicate the significance of the differences between data for control and SC treatment.

$3.11 \%$ in Farm 2). The percentage of milk protein also was positively affected by SC supplementation (2.97 to $3.00 \%$ in Farm 1 and 2.97 to $3.08 \%$ in Farm 2). These positive effects on percentages of milk fat and protein along with increased milk production resulted in increased milk fat yield $(0.06 \mathrm{~kg} / \mathrm{d}$ in Farm 1 and $0.11 \mathrm{~kg} / \mathrm{d}$ in Farm 2) and milk protein yield $(0.03 \mathrm{~kg} / \mathrm{d}$ in Farm 1 and $0.06 \mathrm{~kg} / \mathrm{d}$ in Farm 2) and supports the results seen in the meta-analysis of Poppy et al. (2012).

Average DM intake was approximately $18.8 \mathrm{~kg} / \mathrm{d}$ in this study. Effect of SC on DM intake is dependent on the status of energy balance of cows. When cows were under negative energy balance (<70 DIM), SC increased DMI. However, under positive energy balance (>70 DIM), SC decreased DMI (Poppy et al., 2012). The present study showed DMI in SC supplemented cows was similar to that of nonsupplemented group when averaged for cows from 20 to 140 DIM. However, there was a trend of reducing DMI for cows supplemented with SC compared to control cows as the lactation progressed on Farm 1 but not on Farm 2. Therefore, it was noteworthy that, in the present study, even though the TMR contained $45 \%$ to $48 \%$ forage, there were not grossly overloaded with concentrates, the SC supplementation still had a significant beneficial effect on

Table 5. Effect of yeast culture supplementation (SC) ${ }^{1}$ on LPS concentration $(\mathrm{EU} / \mathrm{ml})^{2}$ in plasma and feces

\begin{tabular}{|c|c|c|c|c|c|c|}
\hline & \multicolumn{2}{|c|}{ Treatment } & \multirow{2}{*}{ SEM } & \multicolumn{3}{|c|}{ p-value } \\
\hline & Control & $\mathrm{SC}$ & & $\mathrm{SC}$ & DIM & $\mathrm{SC} \times \mathrm{DIM}$ \\
\hline \multicolumn{7}{|l|}{ Plasma } \\
\hline Farm 1 & 0.77 & 0.62 & 0.098 & 0.207 & 0.001 & 0.307 \\
\hline Farm 2 & 0.26 & 0.13 & 0.043 & 0.070 & 0.005 & 0.115 \\
\hline \multicolumn{7}{|l|}{ Feces } \\
\hline Farm 1 & 6,915 & 5,748 & 634 & 0.239 & $<0.001$ & 0.327 \\
\hline Farm 2 & 9,643 & 9,137 & 901 & 0.800 & 0.923 & 0.761 \\
\hline
\end{tabular}

${ }^{1} \mathrm{SC}=56 \mathrm{~g} / \mathrm{cow} / \mathrm{d}$, Diamond V Original XP, Diamond V, Cedar Rapids, Iowa, USA.

${ }^{2}$ LPS $=$ Lipopolysaccharide. EU $=$ Endotoxin unit. 


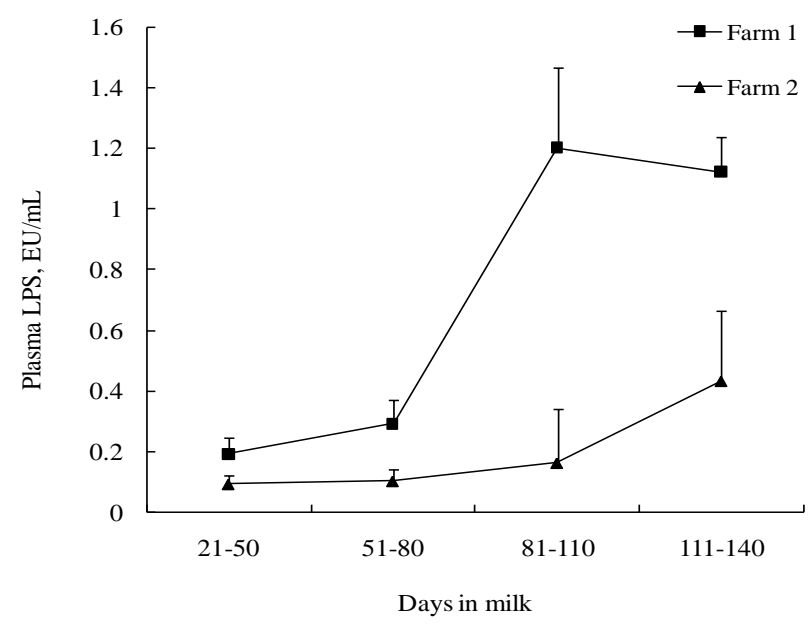

Figure 3. Effect of DIM on plasma lipopolysaccharide (LPS) concentration (Endotoxin Unit (EU)/ml).

lactation performance in both farms. This indicated that the SC supplementation enabled better presentation of the nutritional value of feeds, to increase the concentrate may not be the necessary way to improve the lactation performance considering the health of dairy cows.

Previous research reported that LPS, an endotoxin, could stimulate localized or systemic inflammation via the activation of pattern recognition receptors (Emmanuel et al., 2008). Additionally, LPS and inflammation can regulate intestinal epithelial function by altering integrity, nutrient transport and utilization. The gastrointestinal tract is a large reservoir of both Gram-positive and negative bacteria, of which the Gram-negative bacteria serve as a source of LPS. Recent research has shown that feeding of high concentrate diets is associated with activation of a non-specific acutephase reaction (APR) in both dairies (Emmanuel et al., 2008; Khafipour et al., 2009) and beef cattle (Ametaj et al., 2009). The reason for the activation of a systemic APR is that translocation of LPS into the systemic circulation stimulates the release of pro-inflammatory cytokines such as tumor necrosis factor (TNF)- $\alpha$, interleukin (IL)-1, and IL-6 by liver macrophages (Gabay and Kushner, 1999). This results in enhanced secretion of acute phase proteins (APP) like LPS-binding protein (LBP), serum amyloid A (SAA), and C-reactive protein from hepatocytes (Emmanuel et al., 2008).

Rumen $\mathrm{pH}$ is believed to play a modulatory role on the release and accumulation of LPS due to its effects on metabolic processes and changes in the cell membrane of rumen bacteria, maintenance of bacterial ecological balances, and on other physiological functions of the rumen (Russell and Rychlik, 2001). Ametaj et al. (2010) observed that a strong negative relationship between preprandial rumen $\mathrm{pH}$ and concentration of LPS in the rumen fluid. Thus, rumen $\mathrm{pH}$ modifiers could affect the endotoxin concentration. A previous study showed that SC supplementation to cows in early lactation decreased plasma LPS concentration at 20,40 and $60 \mathrm{~d}$ of feeding (Luo et al., 2005). More recently, Li et al. (2012) reported a reduction of ruminal LPS concentration for cows supplemented with yeast culture when cows were subjected to a sub-acute ruminal acidosis induction. In our study, SC supplementation tended to decrease plasma LPS levels. This effect of SC may be partly explained by the stabilizing effect on rumen fermentation as mentioned early.

\section{CONCLUSION}

Supplementation of SC to lactating dairy cows significantly improved yield of milk and milk components without affecting DMI, which resulted in improved feed efficiency. Plasma LPS concentrations tended to increase as lactation progressed until 140 DIM. Supplemental SC did not influence LPS concentrations although numerical trend toward reducing the plasma LPS concentrations were noted.

\section{ACKNOWLEDGEMENTS}

This study was supported by funds from Diamond V (Cedar Rapids, IA). The authors thank Weiguo Liu (Department of Animal Science, Anhui Institute of Science and Technology, Anhui) for providing the experimental cows from the commercial dairy farms.

\section{REFERENCES}

Ametaj, B. N., K. M. Koenig, S. M. Dunn, W. Z. Yang, Q. Zebeli and K. A. Beauchemin. 2009. Backgrounding and finishing diets are associated with inflammatory responses in feedlot steers. J. Anim. Sci. 87:1314-1320.

Ametaj, B. N., Q. Zebeli and S. Iqbal. 2010. Nutrition, microbiota, and endotoxin-related diseases in dairy cows. R. Bras. Zootec. 39:433-444.

AOAC. 1990. Official methods of analysis. 15th edn. Association of Official Analytical Chemists, Arlington, Virginia.

Callaway, E. S. and S. A. Martin. 1997. Effects of a Saccharomyces cerevisiae culture on ruminal bacteria that utilize lactate and digest cellulose. J. Dairy Sci. 80:2035-2044.

Emmanuel, D. G., S. M. Dunn and B. N. Ametaj. 2008. Feeding high proportions of barley grain stimulates an inflammatory response in dairy cows. J. Dairy Sci. 91:606-614.

Gabay, C. and I. Kushner. 1999. Acute-phase proteins and other systemic responses to inflammation. N. Engl. J. Med. 340: 448-454.

Gozho, G. N., J. C. Plaizier, D. O. Krause, A. D. Kennedy and K. M. Wittenberg. 2005. Subacute ruminal acidosis induces ruminal lipopolysaccharide endotoxin release and triggers an inflammatory response. J. Dairy Sci. 88:1399-1403.

Harrison, G. A., R. W. Hemken, K. A. Dawson, R. J. Harmon and K. B. Barker. 1988. Influence of addition of yeast culture supplement to diets of lactating cows on ruminal fermentation and microbial populations. J. Dairy Sci. 71:2967-2975. 
Khafipour, E., D. O. Krause and J. C. Plaizier. 2009. A grain-based subacute ruminal acidosis challenge causes translocation of lipopolysaccharide and triggers inflammation. J. Dairy Sci. 92:1060-1070.

Krishnamoorthy, U., T. V. Muscato, C. J. Sniffen and P. J. Van Soest. 1982. Nitrogen fractions of selected feedstuffs. J. Dairy Sci. 65:217-225.

Li, S., E. Khafipour, D. O. Krause, A. Kroeker, J. C. RodriguezLecompte, G. N. Gozho and J. C. Plaizier. 2012. Effects of subacute ruminal acidosis challenges on fermentation and endotoxins in the rumen and hindgut of dairy cows. J. Dairy Sci. 95:294-303.

Li, S., D. O. Krause, E. Khafipour and J. C. Plaizier. 2010. Does Subacute ruminal acidosis (SARA) affect fermentation in the hind Gut? WCDS Advances in Dairy Technology. 22:380 (Abstr.).

Li, S., E. Tesfaye, H. Khazane-hei, M. Scott, I. Yoon, E. Khafipour and J. C. Plaizier. 2012. Impact of feeding yeast culture under normal and SARA conditions in lactating dairy cows. J. Anim. Sci. 90 (Suppl. 3):485 (Abstr.).

Longuski, R. A., Y. Ying and M. S. Allen. 2009. Yeast culture supplementation prevented milk fat depression by a short-term dietary challenge with fermentable starch. J. Dairy Sci. 92: 160-167.
Luo, A. Z., C. M. Qi, H. L. Chen, L. Bo, X. Q. Wang and Q. Yan. 2005. Influence of Yikang XP on plasma endotoxin concentration and additional indexes in lactating cows (Chinese). China Dairy Cattle. 2:12-15.

Miller-Webster, T., W. H. Hoover, M. Holt and J. E. Nocek. 2002. Influence of yeast culture on ruminal microbial metabolism in continuous culture. J. Dairy Sci. 85:2009-2014.

National Research Council. 2001. Nutrient requirements of dairy cattle. 7th Ed. National Academy Press, Washington, DC.

Pejsak, Z. and K. Tarasiuk. 1989. The occurrence of endotoxin in sows with coliform mastitis. Theriogenology. 32:335-341.

Poppy, G. D., A. R. Rabiee, I. J. Lean, W. K. Sanchez, K. L. Dorton and P. S. Morley. 2012. A meta-analysis of the effects of feeding yeast culture produced by anaerobic fermentation of Saccharomyces cerevisiae on milk production of lactating dairy cows. J. Dairy Sci. 95:6027-6041.

Russell, J. B. and J. L. Rychlik. 2001. Factors that alter rumen microbial ecology. Science 292:1119-1122.

Van Soest, P. J., J. B. Robertson and B. A. Lewis. 1991. Methods for dietary fiber, neutral detergent fiber, and nonstarch polysaccharides in relation to animal nutrition. J. Dairy Sci. 74:3583-3597.

Yoon, I. and J. E. Garrett. 1998. Yeast culture and processing effects on 24-hour in situ ruminal degradation of corn silage. Proceeding of World Animal Production Conference 1. pp. 322-323. 